\title{
Filter feeding in the burrowing amphipod Corophium volutator
}

\author{
Lene Friis Møller, Hans Ulrik Riisgård*
}

Marine Biological Research Centre, University of Southern Denmark, Hindsholmvej 11, 5300 Kerteminde, Denmark

\begin{abstract}
The present study shows that when suspended phytoplankton cells are present at sufficiently high concentrations the tube-dwelling marine amphipod Corophium volutator (Pallas) filter feeds, but when the phytoplankton biomass reaches a certain low level, both laboratory and field video observations support the hypothesis that $C$. volutator can switch to surface deposit feeding. Feeding behaviour and quantification of water processing were studied in individuals transferred to glass tubes. Simultaneous clearance of algal cells of different size showed that the setae filter on the second gnathopods retains particles $\geq 7 \mu \mathrm{m}$. The pumping rate $\left(P, \mathrm{ml} \mathrm{h}^{-1}\right)$ was measured by video particle tracking, and the relationship between $P$ and body dry weight $(W, \mathrm{mg})$ was found to be $P=53.3 W^{0.76}$. The relationship between $P$ and body length $(L, \mathrm{~mm})$ was $P=0.24 L^{3}+7.8$, and the relationship between temperature $\left(T,{ }^{\circ} \mathrm{C}\right)$ and $P$ was $P=5.55 T+3.3$. The respiration rate of a $6.5 \mathrm{~mm}$ length individual was $0.7 \mu \mathrm{O}_{2} \mathrm{~h}^{-1}\left(15^{\circ} \mathrm{C}\right)$, and by relating respiration to $P$ of an individual of this size, it was estimated that $C$. volutator pumps $108 \mathrm{l}$ water $\mathrm{ml}^{-1} \mathrm{O}_{2}$ consumed, thus fulfilling the conditions for classification as a true filter feeder. Monthly samples were collected for $1 \mathrm{yr}$ from the shallow $(0.8 \mathrm{~m})$ inner part of Odense Fjord (Denmark) in order to follow size and density distribution of $C$. volutator. By combining filtration rate data with size- and temperature-dependent $P$ data, the area-specific population filtration rate varied between 0.9 in January and $19.4 \mathrm{~m}^{3} \mathrm{~m}^{-2} \mathrm{~d}^{-1}$ in June. The half-life of phytoplankton (assuming $100 \%$ particle retention efficiency and efficient vertical mixing of the water column) ranged from $14.5 \mathrm{~h}$ in January to $0.7 \mathrm{~h}$ in June and July. This suggests that the grazing impact of $C$. volutator may be significantly important in the inner Odense Fjord and other shallow water areas with dense populations of $C$. volutator.
\end{abstract}

KEY WORDS: Feeding · Pumping rate · Particle retention efficiency · Respiration · Effect of temperature · Grazing impact

\section{INTRODUCTION}

The tube-dwelling amphipod Corophium volutator (Pallas), which lives in shallow soft sediments of coastal waters around Europe, NE America (Lincoln 1979, Murdoch et al. 1986) and Japan (Omori et al. 1982), feeds on surface sediment or on suspended particles by drawing these food items into its U-shaped tube in the sediment (Hart 1930, Meadows \& Reid 1966, Fenchel et al. 1975, Foster-Smith 1978, Nielsen \& Kofoed 1982, Miller 1984, Hawkins 1985, Gerdol \& Hughes 1994a,b, Riisgård \& Kamermans 2001). In the surface deposit-feeding mode, C. volutator gathers particles from the sediment surface with its enlarged second antennae. In the filter-feeding mode, it extends its body along the tube and feeds by filtering particles from a pleopodal current through a basket formed by the finely plumose setae of the second gnathopods. It has been suggested that $C$. volutator can directly utilise suspended particles, e.g. small planktonic algae and bacteria adsorbed to resuspended mineral particles (Fenchel et al. 1975, Miller 1984), but it seems mainly to be a deposit feeder grazing on the sediment microflora (Gerdol \& Hughes 1994a,b, Hagerthey et al. 2002).

The population density of Corophium volutator is very high in certain areas, with frequently $>40000$ ind. $\mathrm{m}^{-2}$ in the Wadden Sea (Flach 1992, 1993), locally up to 
100000 ind. $\mathrm{m}^{-2}$ on the west coast of Sweden (Möller \& Rosenberg 1982), and up to 140000 ind. $\mathrm{m}^{-2}$ on salt marshes in SE England (Gerdol \& Hughes 1994a). Its high population densities make this amphipod an important part of many mud-flat ecosystems. Thus, in the Bay of Fundy (eastern Canada), C. volutator forms a large part of the diet of ground-feeding fishes and is the major prey of migrating shorebirds (Hawkins 1985, Murdoch et al. 1986).

However, few attempts have been made to study the filter-feeding ability of this amphipod, to assess its possible grazing impact and suggested ability to switch between surface deposit feeding and filter feeding. The aim of the present study was to provide such information through combined experimental laboratory studies and field observations in the shallow inner part of Odense Fjord (Denmark).

Pumping rate was measured in individuals in glass tubes by means of video particle tracking, and particle retention efficiency was determined by simultaneous clearance of algal cells of different size. Monthly samples were collected for $1 \mathrm{yr}$ in order to follow size and density distribution of Corophium volutator. By combining filtration rate data with size- and temperature-dependent pumping rate data, the area-specific population filtration rate was estimated in order to evaluate the potential grazing impact of $C$. volutator. Further, both laboratory and field video observations were used to test the hypothesis that $C$. volutator may switch to surface deposit feeding when the phytoplankton biomass reaches a certain low level.

\section{MATERIALS AND METHODS}

Amphipod collection and storage. Corophium volutator (Pallas) were collected from a mud-flat $(0.8 \mathrm{~m}$; $12 \mathrm{psu}$ ) in the inner Odense Fjord (Denmark) at regular intervals (1 mo) during 2001 and 2002. Sediment samples were sieved (1 $\mathrm{mm}$ mesh size) and the retained amphipods were taken to the laboratory, where they were transferred to straight glass tubes (10 $\mathrm{cm}$ length; 1 to $2.5 \mathrm{~mm}$ internal diameter). The internal diameter of the glass tubes was chosen to fit the size of the amphipods using the linear relation $B D$ $=0.21 L-0.01\left(\mathrm{r}^{2}=0.74, \mathrm{n}=10\right)$ found between burrow diameter $(B D, \mathrm{~mm})$ and body length $(L, \mathrm{~mm})$ measured from rostrum to telson. The amphipods were kept in a storage aquarium $\left(15^{\circ} \mathrm{C} ; 20 \mathrm{psu}\right)$ until experiments could be performed (but for no longer than $1 \mathrm{mo}$ ) and fed daily with a suspension of the diatom Skeletonema costatum.

Water pumping rate. The pumping rate $(P)$ of Corophium volutator in glass tubes was determined by means of particle tracking velocimetry (PTV) using video- microscope recordings of suspended microalgae entering the glass tubes (Riisgård \& Larsen 2005). A video camera (Kappa CF 11/1) attached to an inverted microscope (Labovert FS) and a 50 half-frames $\mathrm{s}^{-1}$ video recorder (Panasonic NV-FS200 HQ) was used. The mean flow velocity $\left(v_{\mathrm{m}}\right)$ was estimated from the distance travelled by the particles between subsequent video frames. Knowing the cross-sectional area of the glass tube $(A)$, $P$ was estimated as $Q_{\text {est }}=A \times v_{\mathrm{m}}$. The PTV method was checked by drawing water through glass tubes at a known flow rate $\left(Q_{\mathrm{m}}\right)$ and comparing this with the $P$ estimated by the PTV method. Such checks were made for 3 different tube sizes (internal diameter, $D=1.1,1.5$ and $2.4 \mathrm{~mm}$ ) at $15^{\circ} \mathrm{C}$; the $1.1 \mathrm{~mm}$ tube was also tested at 3 additional temperatures $\left(5,10\right.$ and $\left.20^{\circ} \mathrm{C}\right)$ (Table 1$)$. The agreement between the 2 methods was satisfactory (slope of regression line for $Q_{\text {est }}$ as a function of $Q_{\mathrm{m}}$ was 1.0 and $r^{2}=0.99$ ). Further, the flow patterns observed for empty glass tubes were compared with those for a water pumping C. volutator (Fig. 1).

To determine the size-dependent $P$ of Corophium volutator, glass tubes with experimental amphipods were placed on a rack in an aquarium $\left(15^{\circ} \mathrm{C}\right)$ with seawater, and Skeletonema costatum were added (about 2000 cells $\mathrm{ml}^{-1}$ ). The same set up was used for studying the feeding behaviour of individuals in glass tubes. The pleopodal beat frequency was determined by counting the number of beats per unit time.

To determine the acute effects of temperature on $P$ and on water pumping pleopod activity, 2 groups of amphipods were collected on 21 April and 10 June 2001 , when the water temperature was 7 and $15^{\circ} \mathrm{C}$, respectively. The 2 groups were kept in the laboratory for $1 \mathrm{wk}$ at the respective field temperatures (controlled by means of a thermostatic water bath) prior to measurement of the acute effects of temperature on 5 individuals from each 'seasonally acclimated' group.

Table 1. Calibration of particle tracking velocimetry (PTV) method. $D$ : internal diameter of glass tube; $A$ : cross-sectional area of glass tube; $T$ : temperature; $V_{\mathrm{m}}$ : mean $( \pm \mathrm{SD}, \mathrm{n}=5)$ water velocity; $Q_{\text {est }}\left(=A \times v_{\mathrm{m}}\right)$ : estimated water flow; $Q_{\mathrm{m}}$ : measured water flow. Flow pattern in inhalant region of glass tube used for estimating $Q_{\text {est }}$ for Tube 1 is shown in Fig. 1A, flow patterns from measurements with water pumping Corophium volutator in the tube in Fig. 1B (corresponding to individual 8 in Table 2)

\begin{tabular}{|lcccccc|}
\hline Tube & $\begin{array}{c}D \\
(\mathrm{~mm})\end{array}$ & $\begin{array}{c}A \\
\left(\mathrm{~mm}^{2}\right)\end{array}$ & $\begin{array}{c}T \\
\left({ }^{\circ} \mathrm{C}\right)\end{array}$ & $\begin{array}{c}V_{\mathrm{m}} \\
\left(\mathrm{mm} \mathrm{s}^{-1}\right)\end{array}$ & $\begin{array}{c}Q_{\mathrm{est}} \\
\left(\mathrm{ml} \mathrm{h}^{-1}\right)\end{array}$ & $\begin{array}{c}Q_{\mathrm{m}} \\
\left(\mathrm{ml} \mathrm{h}^{-1}\right)\end{array}$ \\
\hline 1 & 1.1 & 0.95 & 5 & $7.1 \pm 0.4$ & 24 & 24 \\
2 & 1.1 & 0.95 & 10 & $7.0 \pm 0.7$ & 24 & 24 \\
3 & 1.1 & 0.95 & 15 & $5.5 \pm 0.4$ & 19 & 22 \\
4 & 1.1 & 0.95 & 20 & $7.4 \pm 0.6$ & 25 & 27 \\
5 & 1.5 & 1.8 & 15 & $5.9 \pm 0.2$ & 38 & 35 \\
6 & 2.4 & 4.5 & 15 & $4.4 \pm 0.2$ & 72 & 76 \\
\hline
\end{tabular}


Clearance rate. The clearance rate was measured as the volume of water cleared of algal cells per unit time. Algal cells were added to an aquarium with experimental amphipods transferred to glass tubes submerged in seawater containing a suspension of single-cell Skeletonema costatum, and the exponential decrease in algal concentration was followed by analysing water samples with an electronic particle counter (Elzone 80xy). Clearance was estimated from the slope of the regression line in a semi-ln plot as $\mathrm{Cl}=$ slope $\times V / n$, where $V=$ volume of water (l), and $n=$ number of actively pumping amphipods. (For particles retained with $100 \%$ efficiency by the Corophium volutator setae filter, clearance rate $=$ filtration rate $=$ pumping rate). $\mathrm{Cl}$ measurements were made using algal cells of different diameter (Isochrysis sp. $4 \mu \mathrm{m}$, Rhodomonas sp. $6.4 \mu \mathrm{m}$, and S. costatum $11 \mu \mathrm{m})$. Control experiments without amphipods were used to correct for sedimentation. All experiments were performed at $15^{\circ} \mathrm{C}$.

Filter structure. The filter structure was studied by means of the microscope video system in dissected limbs as well as in intact water pumping individuals transferred to glass tubes.

Population studies. Population densities and size distributions of Corophium volutator were determined in Odense Fjord during 2001 by taking 5 quantitative bottom core samples (diameter $=52 \mathrm{~mm}$ ) each month for subsequent analysis in the laboratory. The sediment was sieved through an $0.5 \mathrm{~mm}$ sieve, and the retained $C$. volutator were counted and their length measured.

Respiration. The respiration rate of Corophium volutator was measured as oxygen consumption, using an oxygen electrode (CellOx 325) connected to an oxygen measuring instrument (Oxi 197i). The electrode was placed in a flow-through chamber connected to the respiration chamber containing the experimental amphipods, and $100 \%$ oxygen-saturated filtered seawater was pumped through the respiration and elec- trode chambers by means of a peristaltic pump. Measurements were made by closing the system so that water was recirculated past the electrode. The oxygen concentration $\left(\mathrm{mg} \mathrm{O}_{2} \mathrm{l}^{-1}\right.$ ) was plotted as a function of time and expressed by a regression line. The respiration rate was calculated as $R\left(\mathrm{mg} \mathrm{O}_{2} \min ^{-1}\right)=b \times V / n$, where $b=$ the slope of the regression line $\left(\mathrm{mg} \mathrm{O} \mathrm{O}^{-1}\right.$ $\left.\mathrm{min}^{-1}\right), V=$ volume of water in the respiration system (l), and $n=$ number of amphipods. The amphipods were freely swimming in the respiration chamber, and 3 series of measurements were conducted, each followed by a control measurement without amphipods. All measurements were made at $15^{\circ} \mathrm{C}$.

Population clearance rates and switching of feeding mode. An experimental aquarium $(30 \times 31 \times 49.5 \mathrm{~cm})$ was filled with $15 \mathrm{~cm}$ sieved $(1 \mathrm{~mm})$ autoclaved sediment from the amphipod collection site in Odense Fjord on 20 April 2002. The sediment was illuminated by a greenhouse lamp (Philips SON-T, $400 \mathrm{~W}$ ) in a 12:12 h light:dark cycle to establish benthic diatoms on the sediment surface. A flow of biofiltered (Mytilus edulis) seawater was established through the experimental aquarium, and 4 air stones provided air and mixing. The algae Tetraselmis sp. (mean diameter $8.6 \mu \mathrm{m})$ was used for the experiments, and the algal concentration was measured with an electronic particle counter (Elzone 80xy). Prior to adding the amphipods to the experimental aquarium, a control experiment without amphipods was set up to determine the sedimentation rate of algal cells.

We added 400 Corophium volutator $(L=6.7 \pm$ $0.7 \mathrm{~mm}$ ), corresponding to 2600 ind. $\mathrm{m}^{-2}$ to the experimental aquarium, and allowed them to acclimatise for at least $1 \mathrm{wk}$ before commencing the experiments. We carried out 5 experiments (A to E); Expts A to C were designed for measurement of the population filtration rate, while Expts D to E were conducted primarily to determine if $C$. volutator is able to switch between deposit surface feeding and filter feeding. In Expts A to E, Tetraselmis sp. cells were added continuously by
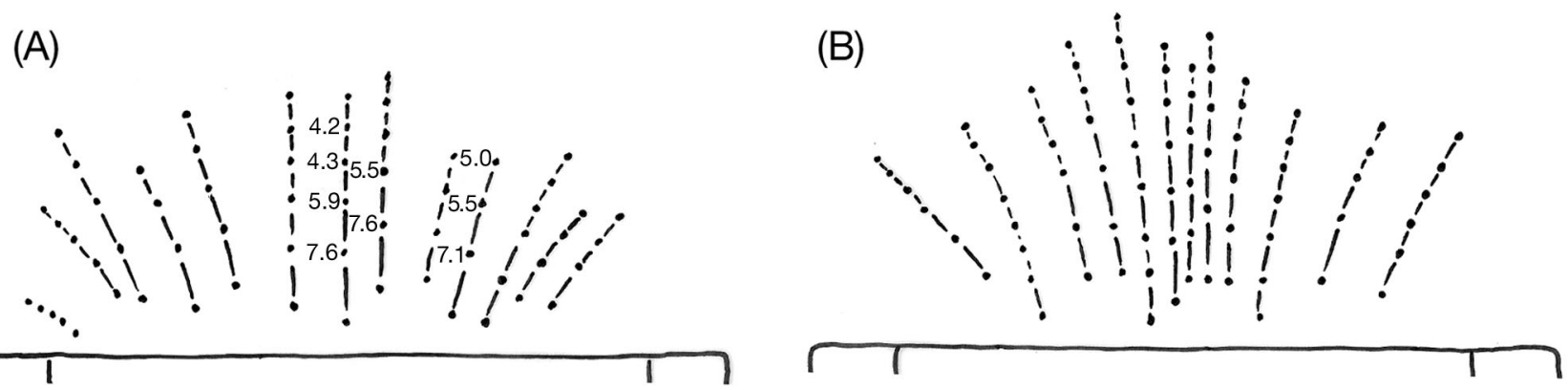

Fig. 1. Sink-flow patterns in inhalant region of glass tubes (A) without and (B) with a water pumping Corophium volutator (based on video pictures). Distance between dots represents $0.1 \mathrm{~s}$ between subsequent video frames. Numbers are local flow velocities $\left(\mathrm{mm} \mathrm{s}^{-1}\right)$. Inner diameters of tubes were 1.1 and $1.5 \mathrm{~mm}$ for $(\mathrm{A})$ and $(\mathrm{B})$, respectively 
means of a peristaltic pump until steady-state was established at ca. 3000 cells $\mathrm{ml}^{-1}$. At steady-state, the filtration rate $(=C l$ of $100 \%$ efficiently retained algal cells) was calculated as $F_{\mathrm{s}}\left(\mathrm{ml} \mathrm{h}^{-1}\right.$ ind.$\left.^{-1}\right)=\left(D R \times C_{\mathrm{c}}-O\right.$ $\times C_{\mathrm{a}} /\left(n \times C_{\mathrm{a}}\right)$ (Riisgård \& Randløv 1981), where $D R=$ dosing rate of algal culture $\left(\mathrm{ml}\right.$ time $\left.{ }^{-1}\right), C_{C}$ and $C_{a}=$ algal concentration (cells ml ${ }^{-1}$ ) in the culture flask and experimental aquarium, respectively, $O=$ throughflow of filtered seawater $\left(\mathrm{ml}\right.$ time $\left.^{-1}\right)$, and $n=$ number of filter-feeding amphipods.

After an initial steady-state had been established, the algal dosing pump was stopped. In Expts A to C, the flow was stopped and the clearance rate $\left(F_{\mathrm{cl}}, \mathrm{ml} \mathrm{h}^{-1}\right.$ ind. ${ }^{-1}$ ) was measured from the exponential reduction in algal concentration as described above in 'Clearance rate'. In and after Expts D to E, the chlorophyll $a$ (chl a) concentration in the water column was measured.

Because of reproduction of the amphipods after Expt A, their density and size distribution changed and was not known in Expts B to C. After Expt E, the number and size distributions of Corophium volutator were determined in representative sediment samples.

Feeding activity. Surface deposit-feeding activity of Corophium volutator was registered in Expts A to E by underwater video recordings using a digital video camera, Sony (DCR-TRV 25 E) Digital Handycam in an underwater housing (Ikelite, Digetal). Sequences of $2 \mathrm{~s}$ were automatically recorded at $1 \mathrm{~min}$ intervals. The filmed area was $5.3 \times 7.3 \mathrm{~cm}$. On a photo from every recording, the number $(n)$ of deposit feeding amphipods (individuals $\geq 5 \mathrm{~mm}$ ) was counted. Surface activity was estimated in 2 ways: (1) as $A_{\text {tot }}=n / N_{\text {obs }}$ where $N_{\text {obs }}$ is the total number of amphipods observed in the filmed area, and (2) as $A_{\text {sum }}=n_{\text {sum }} / N_{\text {obs, }}$ where $n_{\text {sum }}$ is summed over intervals of $10 \mathrm{~min}$. $A_{\text {tot }}$ provides an estimate of the surface activity at a given time; in all 'population clearance experiments' the number of apparently actively filter-feeding amphipods was calculated by subtracting the percentage of deposit feeding amphipods $\left(A_{\text {tot }}\right)$ from the total number of amphipods. $A_{\text {sum }}$ gives a measure of change in frequency of surface activity and was used in Expts D and $E$ to evaluate changes in surface activity.

Field study. Possible switching between deposit and suspension feeding in Corophium volutator was investigated in the inner part of Odense Fjord on 2 days in July 2003, using a simple platform to enable water sampling for chl a measurement and underwater video recording of the sediment surface. For isokinetic sampling, we used syringes to collect water samples (50 ml) at 15 to $20 \mathrm{~min}$ intervals from several depths above the bottom, through thin silicone pipes. The samples were filtered (GF/C filters), extracted in $10 \mathrm{ml} 96 \%$ ethanol and the fluorescence measured on a Sequoia-
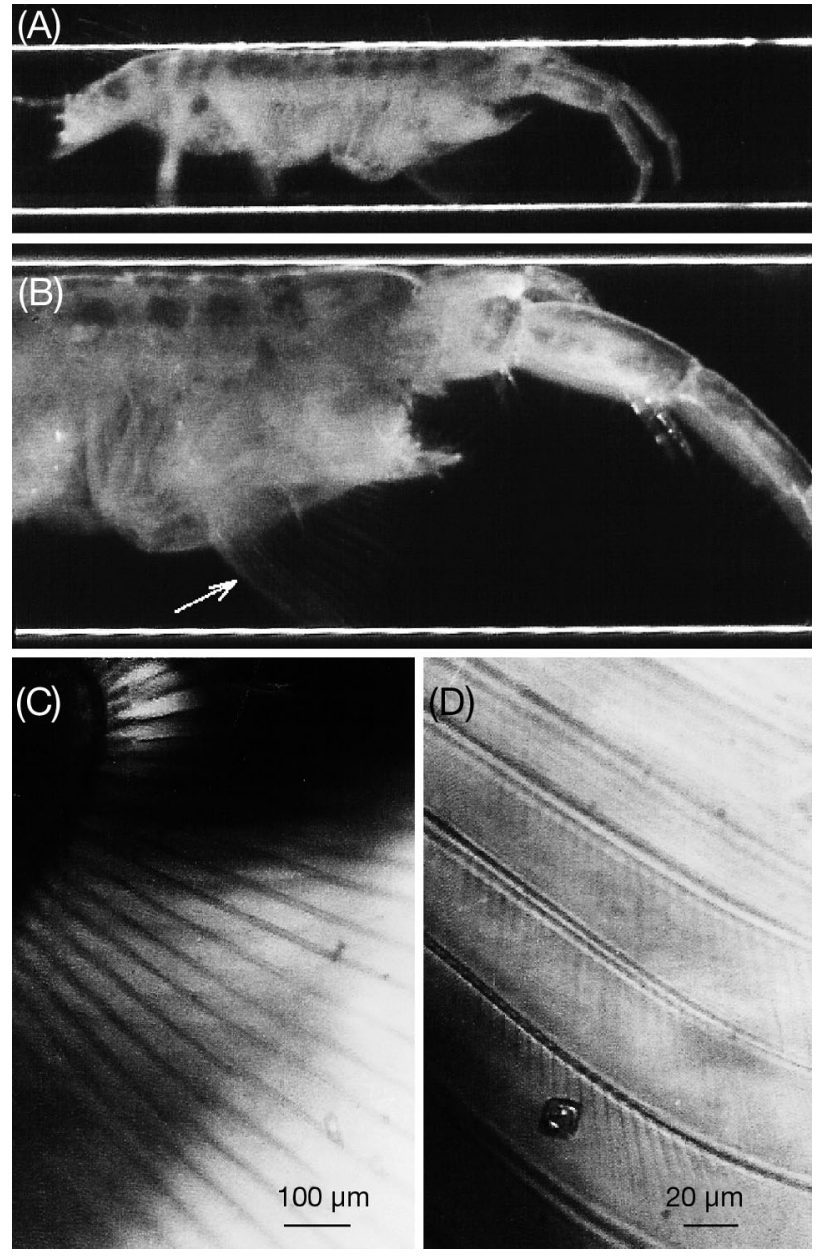

Fig. 2. Corophium volutator. (A) Actively filter-feeding individual in glass tube; beating pleopods and setae filter on second gnathopods are visible. (B) Head region with setae filter (arrow) spread out to close space between the amphipod and tube wall. (C) Setae filter in filtering individual with retained suspended material visible. (D) Close-up of setae filter; setae are clearly visible, bristles only faintly so; retained diatom (Skeletonema costatum) is visible on filter

Turner 450 fluorometer the following day. At $1 \mathrm{~h}$ intervals (or as near to this as possible) a water sample (5 l) was taken from the surface for subsequent extraction and quantification of chl a against a standard to derive a correlation between fluorescence and chl a. Surface deposit-feeding activity of $C$. volutator was registered by means of underwater video recordings (Sony, DCRTRV 25 E) as described for the laboratory experiments (see 'Water pumping rate' above). At the end of the investigations, sediment samples from a known area of the sea floor were analysed to determine the abundance and size distributions of $C$. volutator.

Conversion factors. The relationship between chl a $\left(\mu \mathrm{g} \mathrm{l}^{-1}\right)$ and algal concentration $\left(C_{1} \times 10^{3}\right.$ cells $\mathrm{ml}^{-1}$ ) for Skeletonema costatum was chl $a=2.7 \times C$, for Rhodo- 
monas sp. was chl $a=2.7 \times C$, and for Tetraselmis sp. was chl $a=2.7 \times C$. The dry weight of Corophium volutator was calculated as DW $(\mathrm{mg})=0.0082 L^{2.775}$, where $L=$ body length (mm) (Hawkins 1985). The correlation between DW and wet weight (WW, mg) of $C$. volutator was $\log \mathrm{DW}=-0.591+1.022 \log \mathrm{WW}(\mathrm{Cam}-$ men et al. 1990). The correlation between $R\left(\mu g \mathrm{O}_{2} \mathrm{~h}^{-1}\right)$ and DW of $C$. volutator $\left(15^{\circ} \mathrm{C}\right)$ was $R=0.49 \mathrm{DW}+0.26$ (Hawkins 1985).

\section{RESULTS}

\section{Water processing and particle retention}

Feeding and ventilation behaviour of Corophium volutator was observed in individuals transferred to glass tubes submerged in seawater containing a suspension of single-cell Skeletonema costatum. In such tubes, C. volutator extends its body along the tube wall and, by metachronal beating of the 3 pairs of pleopods, creates a water flow through the tube (Fig. 2A). The filter consists of setae on the second gnathopods that are extended anteriorly, laterally and ventrally to the tube wall forming a basket (Fig. 2B). Almost all water is forced to pass through this filter, since the amphipod lies with its dorsal side against the tube/burrow wall. The amphipods frequently turned around in the tubes but soon after resumed pumping. In general, $C$. volutator pumped continuously and no periodical ventilation was observed during 0.5 to $1 \mathrm{~h}$ periods of observation.

Particle capture on the filter was observed (Fig. 2C,D). At regular intervals the amphipods cleaned the filter by sweeping their second gnathopods under the head region, combing the retained food particles from the filter by the setae on the first gnathopods and subsequently transporting them to the mouth.

Table 2 shows the measured $P$ along with $L$ and pleopodal beat frequency. A linear relationship was found between $P$ and body DW in a log-log plot (Fig. 3A), and between $P$ and $L$ (raised to the third power) (Fig. 3B). A decreasing linear relationship was also found between $L$ and the corresponding pleopod beat frequency (Fig. 3C). Based on the data in Table 2, only a weak correlation was found between $L$ and $v_{\mathrm{m}}\left(\mathrm{mm} \mathrm{s}^{-1}\right)$ in the tube $\left(v_{\mathrm{m}}=\right.$ $\left.0.3 L+4.6 ; r^{2}=0.13, \mathrm{n}=15\right)$. This indicates that the pleopod beat frequency may adjust to $A$ in such a way that the water velocity through the tube, and thus the pressure drop across the setae filter, remain fairly constant, independent of body size.
Typical examples of clearance experiments with Corophium volutator feeding on single-cell Skeletonema costatum are shown in Fig. 4. In all cases, an exponential decrease in algal concentration over time was observed, and the mean filtration rate was $64 \pm$ $5.9 \mathrm{ml} \mathrm{h}^{-1}$ for the $6.3 \pm 0.21 \mathrm{~mm}$ long individuals used in the experiments. For an individual of this size, $P$ is estimated from Fig. 3B to be $68 \mathrm{ml} \mathrm{h}^{-1}$, and this agreement between the 2 methods indicates that the $S$. costatum algal cells used in the clearance experiments were retained by the setae filter with approximately $100 \%$ efficiency.

The filter structure was studied in dissected limbs as well as in intact suspension-feeding individuals in a glass tube (Fig. 2D). The average distance between the centres of the bristles was $7.0 \pm 0.9 \mu \mathrm{m}$, the space between the bristles $6.4 \pm 1.2 \mu \mathrm{m}$. From these observations the filter can be expected to efficiently retain particles of $\geq 7 \mu \mathrm{m}$; this is supported by the experiments on particle retention efficiency in Fig. 5, which shows that $11 \mu \mathrm{m}$ particles are retained with $100 \%$ efficiency (i.e. $C l=P$ ) while the retention of 6.5 and $4.0 \mu \mathrm{m}$ particles is considerably lower.

\section{Effect of temperature}

The acute effect of temperature on $P$ and pleopod beat frequency was measured in 2 groups of Corophium volutator seasonally acclimated to $7^{\circ} \mathrm{C}$ (April) and $15^{\circ} \mathrm{C}$ (June), respectively. For individuals acclimated to $7^{\circ} \mathrm{C}$ (Fig. 6A), there was a linear relationship between temperature and beat frequency in the temperature

Table 2. Corophium volutator. Pumping rate $(P)$ determined by PTV method for 17 individuals of different body length $(L)$ transferred to glass tubes. $D$ : internal diameter of glass tube; $A$ : cross-sectional area of glass tube; $V_{\mathrm{m}}$ : mean $( \pm \mathrm{SD}, \mathrm{n}=5)$ water velocity; $B$ : pleopod beat frequency $( \pm \mathrm{SD}, \mathrm{n}=5)$

\begin{tabular}{|lcccccc|}
\hline Ind. & $\begin{array}{c}L \\
(\mathrm{~mm})\end{array}$ & $\begin{array}{c}D \\
(\mathrm{~mm})\end{array}$ & $\begin{array}{c}A \\
\left(\mathrm{~mm}^{2}\right)\end{array}$ & $\begin{array}{c}V_{\mathrm{m}} \\
\left(\mathrm{mm} \mathrm{s}^{-1}\right)\end{array}$ & $\begin{array}{c}B \\
(\mathrm{~Hz})\end{array}$ & $\begin{array}{c}P \\
\left(\mathrm{ml} \mathrm{h}^{-1} \text { ind }^{-1}\right)\end{array}$ \\
\hline 1 & 3.0 & 1.0 & 0.79 & $4.7 \pm 0.5$ & $6.8 \pm 0.5$ & 13 \\
2 & 3.4 & 1.1 & 0.95 & $6.1 \pm 0.8$ & $5.9 \pm 0.8$ & 21 \\
3 & 3.2 & 1.1 & 0.95 & $5.8 \pm 0.8$ & $7.1 \pm 0.0$ & 20 \\
4 & 5.5 & 1.5 & 1.8 & $4.6 \pm 0.3$ & $5.6 \pm 0.2$ & 29 \\
5 & 5.3 & 1.5 & 1.8 & $7.5 \pm 1.7$ & $6.3 \pm 0.5$ & 48 \\
6 & 4.7 & 1.5 & 1.8 & $4.5 \pm 0.5$ & $5.3 \pm 0.3$ & 29 \\
7 & 5.3 & 1.5 & 1.8 & $5.8 \pm 0.7$ & $5.7 \pm 0.0$ & 37 \\
8 & 4.6 & 1.5 & 1.8 & $6.7 \pm 1.5$ & $4.5 \pm 0.0$ & 43 \\
9 & 5.1 & 1.5 & 1.8 & $7.0 \pm 0.4$ & & 45 \\
10 & 6.0 & 1.6 & 2.0 & $7.5 \pm 0.9$ & $5.3 \pm 0.3$ & 54 \\
11 & 5.7 & 1.7 & 2.3 & $7.1 \pm 0.7$ & $4.9 \pm 0.5$ & 58 \\
12 & 5.7 & 1.7 & 2.3 & $7.4 \pm 1.0$ & $4.5 \pm 0.0$ & 60 \\
13 & 7.0 & 2.2 & 3.8 & $5.2 \pm 0.4$ & $3.9 \pm 0.2$ & 71 \\
14 & 7.0 & 2.2 & 3.8 & $6.3 \pm 0.7$ & $4.1 \pm 0.6$ & 86 \\
15 & 6.8 & 2.5 & 4.9 & $4.8 \pm 0.7$ & $4.9 \pm 1.2$ & 85 \\
16 & 7.5 & 2.4 & 4.5 & $7.9 \pm 0.5$ & & 128 \\
17 & 7.5 & 2.4 & 4.5 & $7.4 \pm 0.4$ & & 118 \\
\hline
\end{tabular}



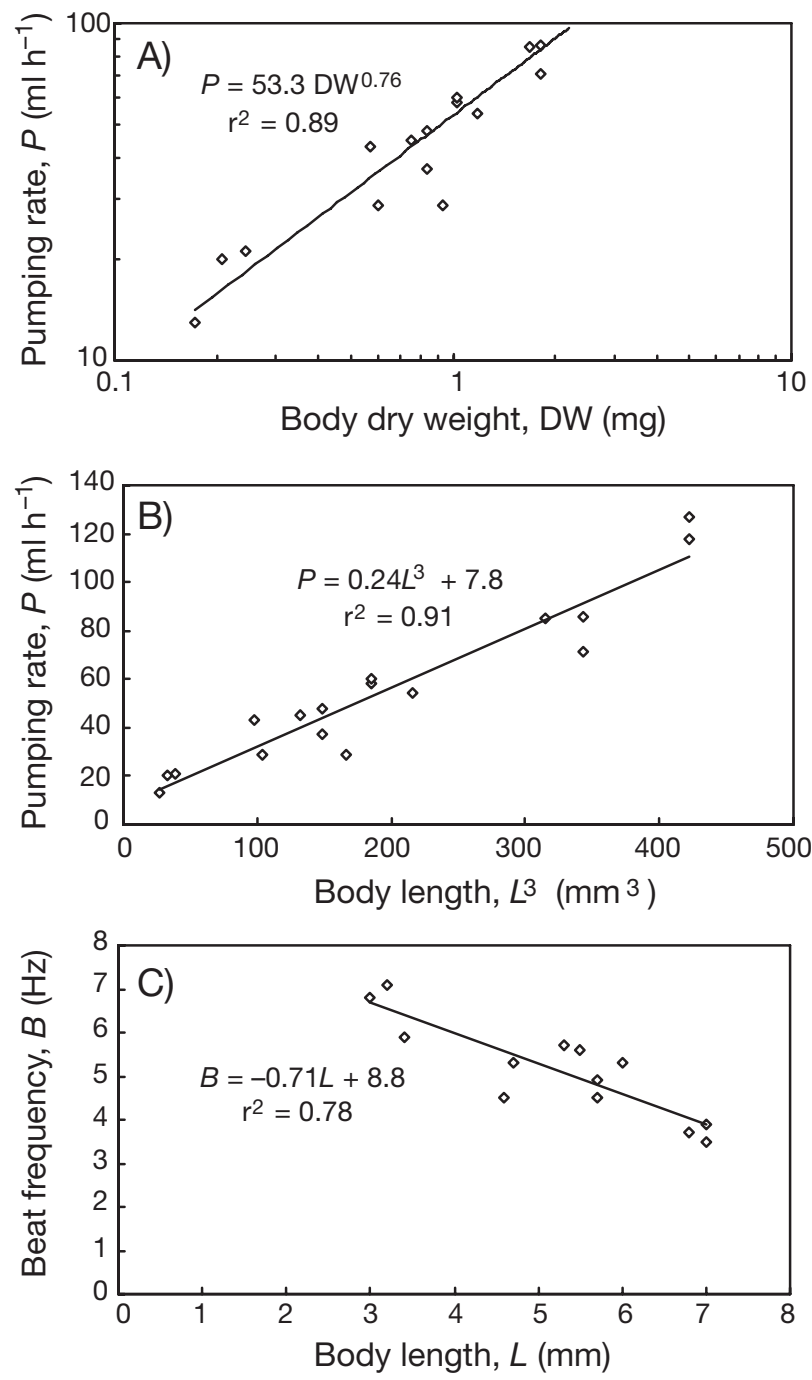

Fig. 3. Corophium volutator. (A) Pumping rate (=filtration rate) as a function of body dry weight; (B) pumping rate as a function of body length raised to the third power; $(\mathrm{C})$ beat frequency of pleopods as a function of body length. Regression lines and equations are shown. All experiments were run at $15^{\circ} \mathrm{C}$

interval 6.5 to $15^{\circ} \mathrm{C}$; above this range the beat frequency rapidly decreased. For individuals acclimated to $15^{\circ} \mathrm{C}$, there was a linear relationship between temperature and beat frequency, and between temperature and $P$ (Fig. 6B) over the entire temperature range of 5 to $23^{\circ} \mathrm{C}$. Further, the relationship between $P$ and pleopod beat frequency was linear (Fig. 6C).

\section{Respiration}

$R$ was determined for $6.5 \pm 0.4 \mathrm{~mm}$ length individuals (outside their tubes) to be $0.7 \pm 0.08 \mu \mathrm{O}_{2} \mathrm{~h}^{-1}\left(15^{\circ} \mathrm{C}\right)$. By relating this rate to the water processing capacity of an individual of this size (from data in Fig. 3B) it is estimated that Corophium volutator pumps 108 l water $\mathrm{ml}^{-1} \mathrm{O}_{2}$ consumed.

\section{Population studies and switching of feeding mode}

During 2001, monthly samples were collected from the inner part of Odense Fjord to estimate the annual size and density of Corophium volutator. By combining the population data with size- and temperature-dependent pumping rate data (Figs. 3B \& 6B), the potential areaspecific population filtration rate $\left(F_{\text {pop }}\right)$ was estimated (Table 3). $F_{\text {pop }}$ varied between 0.9 in January and $19.4 \mathrm{~m}^{3} \mathrm{~m}^{-2} \mathrm{~d}^{-1}$ in June. The potential grazing impact of $C$. volutator can be expressed either as the ratio between the overlying water column $\left(U, \mathrm{~m}^{3}\right)$ and $F_{\text {pop }}: Q=U / F_{\text {pop }}$ (in days). Another estimate for the potential grazing impact is the half-life time of phytoplankton assuming $100 \%$ particle retention efficiency and efficient vertical mixing of the water column, expressed as: $t_{1 / 2}=U / F_{\text {pop }} \times$ $\ln 2$. In the present case, with a water depth of $0.8 \mathrm{~m}$ at the study site, $Q$ ranged from $20.9 \mathrm{~h}$ in January to $1.0 \mathrm{~h}$ in June/July, and $t_{1 / 2}$ ranged from 14.5 to $0.7 \mathrm{~h}$.

The population filtration rate of amphipods actively pumping in their natural burrows in the sediment was measured by means of both the 'steady-state method' $\left(F_{\mathrm{s}}\right)$ and the 'clearance method' $\left(F_{\mathrm{cl}}\right)$ (Table 4). Agreement was found between the 2 methods in Expts A, B and $C$. Therefore, only $F_{\mathrm{s}}$ was determined in Expts D and E. From the measured values of $F_{\mathrm{s}}, F_{\text {pop }}$ was subsequently estimated to vary between 3.2 and $10.4 \mathrm{~m}^{3} \mathrm{~m}^{-2}$ $\mathrm{d}^{-1}$, depending on temperature, population density and size distribution. From measurements on Corophium volutator populations of known density and size distribution (Expts A, D, E, Table 4), the individual filtration rate $\left(F_{\mathrm{i}}\right)$ was estimated. These values were compared to filtration rates estimated from regression lines $\left(F_{i, \text { est }}\right)$ obtained in experiments with amphipods in glass tubes (Figs. 3B \& 6B), and Table 4 shows that there is good agreement between $F_{\mathrm{i}}$ and $F_{\mathrm{i}, \text { est }}$. The number of actively filter-feeding $C$. volutator was 88 to $89 \%$ of the total population in Expts A, $\mathrm{B}$ and $\mathrm{C}$, and 94 to $96 \%$ in Expts D to E.

As an example, the results obtained in Expt B are shown in Fig. 7. The concentration of Tetraselmis sp. at equilibrium (steady-state) was about 3000 cells $\mathrm{ml}^{-1}$, and $F_{\mathrm{s}}$ was calculated at $0.96 \mathrm{~m}^{3} \mathrm{~d}^{-1}$, corresponding to an $F_{\text {pop }}$ of $6 \mathrm{~m}^{3} \mathrm{~m}^{-2} \mathrm{~d}^{-1}$. In the subsequent 2 clearance experiments, $F_{\mathrm{cl}}$ was estimated at 0.80 and $0.88 \mathrm{~m}^{3} \mathrm{~d}^{-1}$, respectively, in good agreement with the preceding steady-state measurement.

Fig. 8 shows 2 experiments (D and E, Table 4) examining $A_{\text {sum }}$ of Corophium volutator as a function of algal concentration in the aquarium. In Expt D in Fig. 8A, no 

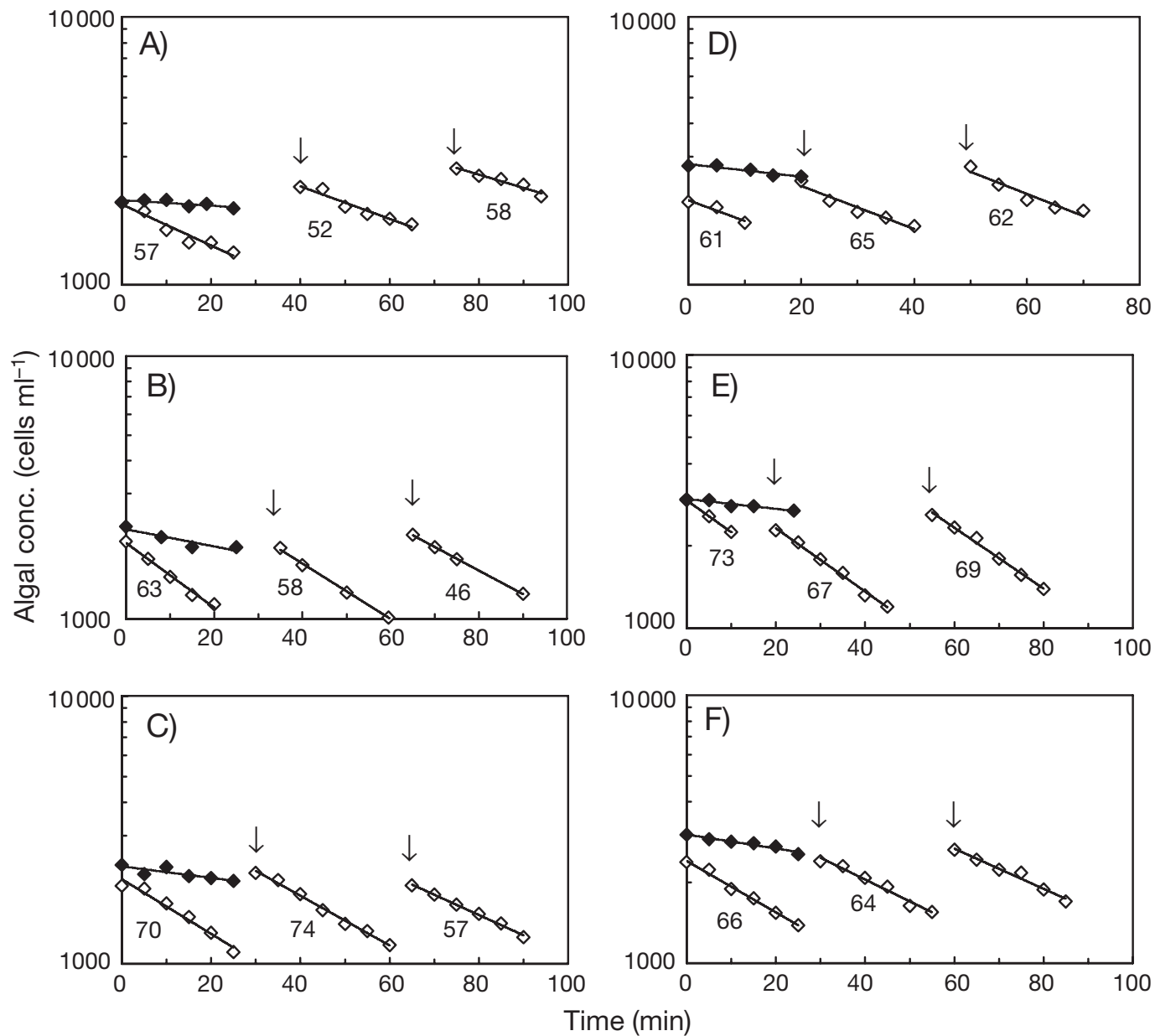

Fig. 4. Corophium volutator. Exponential reduction in algal cell concentration (Skeletonema costatum) in 6 series of clearance experiments $(\mathrm{A}-\mathrm{F})$ due to filtration by $C$. volutator $\left(15^{\circ} \mathrm{C}\right) .(\diamond)$ Estimated clearance rates $\left(\mathrm{ml} \mathrm{h}^{-1}\right.$ ind. $\left.{ }^{-1}\right)$ are indicated below the regression lines; $(\diamond)$ control experiments without amphipods, to correct for sedimentation. Arrows indicate new additions of algal suspension

surface feeding activity was observed when the algal dosing pump was turned on, but when algae addition ceased and the algal concentration declined to about 800 cells ml $^{-1}\left(=0.96 \mu \mathrm{g}\right.$ chl a $\left.{ }^{-1}\right)$, surface activity increased. In Expt E in Fig. 8B, surface feeding activity was low during algae addition, but when the dosing pump was switched off and algal concentration had

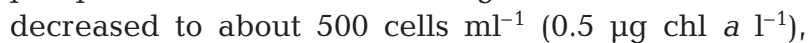
surface activity seemed to increase. This indicates that C. volutator may switch from suspension feeding to surface deposit feeding when the algal concentration drops below a certain lower 'trigger' level.

On 2 d in July 2003, underwater video observations of surface activity of Corophium volutator were made in the inner part of Odense Fjord; however only $10 \%$ of the amphipods video recorded were visible in the recordings due to the small size of most individuals in the field. The surface activity of $C$. volutator, as well as the surface deposit feeding activity of the facultative filter-feeding polychaete Nereis diversicolor (which inhabits the same locality and was therefore simultaneously recorded) is shown in Fig. 9. All field measurements were made while the water level was declining from 23 to $12 \mathrm{~cm}$ on the first day, and from 36 to $7 \mathrm{~cm}$

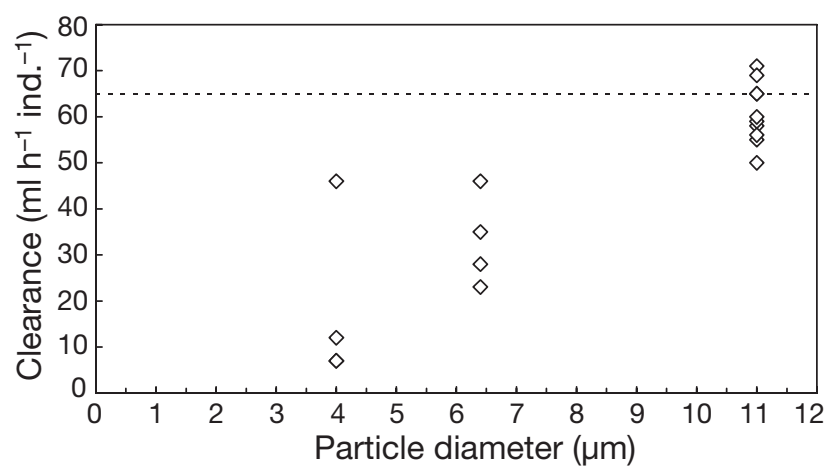

Fig. 5. Corophium volutator. Simultaneously measured clearance rate of 3 algal species of different size $\left(15^{\circ} \mathrm{C}\right)$. Dashed line indicates pumping rate measured by particle tracking velocimetry (PTV) method 

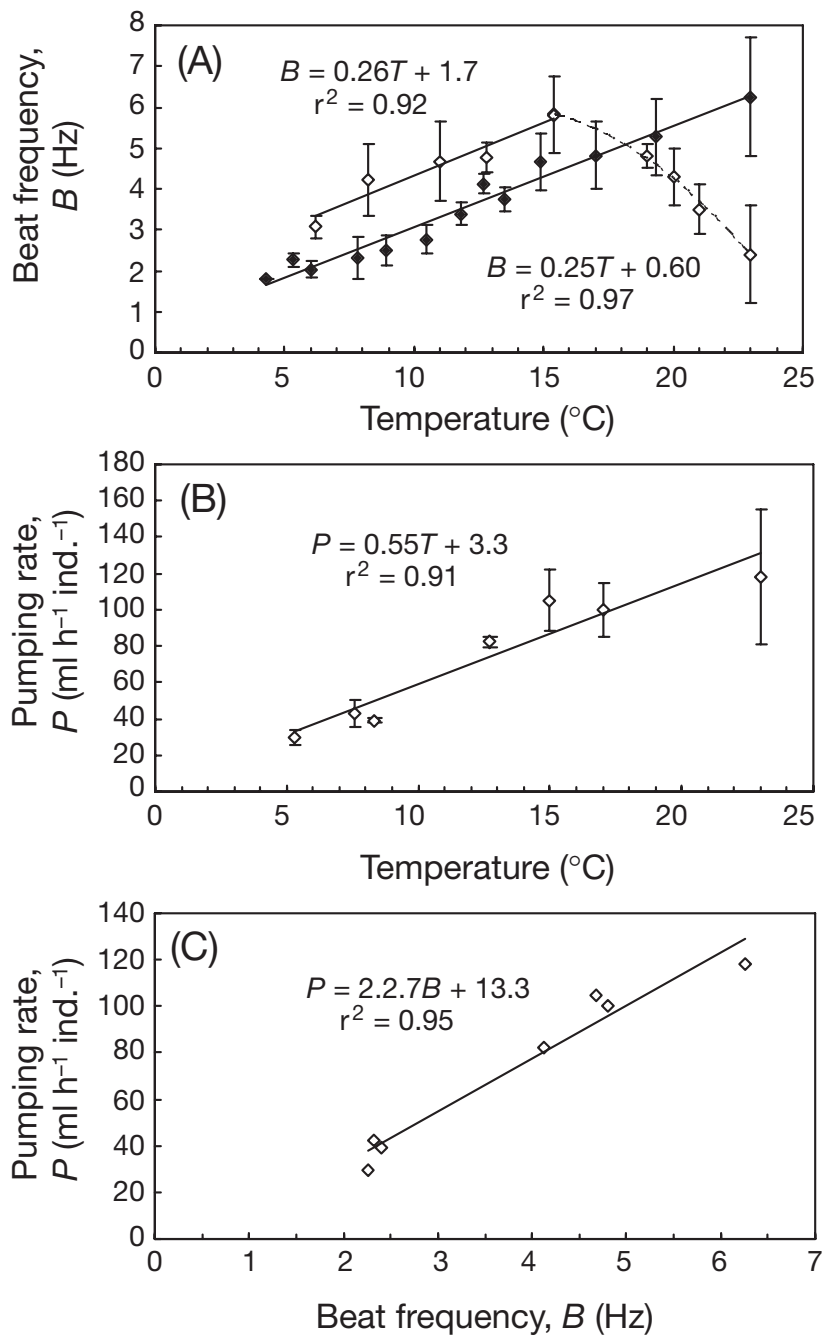

Fig. 6. Corophium volutator. (A) Beat frequency of waterpumping pleopods as a function of temperature in individuals seasonally acclimated to $7^{\circ} \mathrm{C}(\diamond)$ and $15^{\circ} \mathrm{C}(\diamond)$; regression line and equation shown for temperature interval in which linear relationship is suggested. (B) Pumping rate (=filtration rate) as a function of temperature measured by PTV method for $15^{\circ} \mathrm{C}$ group in (A). (C) Pumping rate as a function of pleopod beat frequency. Regression lines and equations are shown. Data are means $( \pm \mathrm{SD})$

on the following day (Fig. 9D,H). On 22 July, surface activity was highest at the beginning of the observation period (12:00 to $12: 43 \mathrm{~h}$ ), when it was 20 to $35 \%$ for C. volutator and 15 to $30 \%$ for $N$. diversicolor. During this period, chl a concentration was 3 to $6 \mu \mathrm{g} \mathrm{l}^{-1}$, the lowest recorded on this day. Later (13:50 h), when chl a had increased to about $10 \mu \mathrm{g} \mathrm{l}^{-1}$, almost no surface activity was observed for either $C$. volutator or $N$. diversicolor. On the following day, both species showed a relatively high surface activity at the beginning of the observation period (11:16 to $\sim 11: 55 \mathrm{~h})$, but later $(\sim 13: 30 \mathrm{~h})$, when the chl a concentration dropped $\left(0.5\right.$ to $\left.2 \mu \mathrm{g} \mathrm{l}^{-1}\right)$, surface activity increased in $N$. diversi- color, but remained low in C. volutator. In general, the field observations support the hypothesis that both $C$. volutator and $N$. diversicolor can switch to surface deposit feeding when the phytoplankton biomass reaches a certain low level.

\section{DISCUSSION}

The present observations of filter feeding in Corophium volutator (Fig. 2) are in agreement with earlier observations of Hart (1930), Meadows \& Reid (1966) and Miller (1984). Periodical ventilation in C. bonelli was reported by Foster-Smith \& Shillaker (1977), but the present study indicates that (although the amphipod frequently turns around in its tube, thereby reversing the flow direction) water pumping activity of $C$. volutator in the presence of algal cells in the ambient water is more persistent, and seems to be in good agreement with the data of Taylor (1985) and Harris \& Musko (1999), who studied C. volutator and C. curvispinum, respectively.

The Corophium volutator filter is made up of fine bristles on the setae of the first and second pair of gnathopods (Fig. 2) and the distance between the bristles was found to range from 6.4 to $7.0 \mu \mathrm{m}$, which is somewhat larger than reported by Fenchel et al. (1975) and Nielsen \& Kofoed (1982). The filter dimensions indicate that the setae filter may efficiently retain particles $\geq 7 \mu \mathrm{m}$, an assumption that is supported by the present particle retention efficiency experiments which showed that $11.0 \mu \mathrm{m}$ particles are retained with $100 \%$ efficiency while the retention of 6.5 and $4.0 \mu \mathrm{m}$ particles is strongly reduced (Fig. 5). Further, since $8.6 \mu \mathrm{m}$ Tetraselmis sp. cells are cleared at the same rate as $11.0 \mu \mathrm{m}$ Skeletonema costatum cells (cf. $F_{\mathrm{i}}$ and $F_{\mathrm{i} . e s t}$, Table 4), the lower threshold for efficient particle retention is ca. $7 \mu \mathrm{m}$. From stomach analyses, Fenchel et al. (1975) observed that $C$. volutator ingests particles in the size range of 4 to $63 \mu \mathrm{m}$, but that only a low percentage of the ingested particles is $4 \mu \mathrm{m}$. This indicates that bacteria in suspension can only be retained by $C$. volutator if the bacteria are adsorbed to re-suspended mineral particles $\geq 7 \mu \mathrm{m}$.

The present study measured $P$ as a function of size in Corophium volutator for the first time (Fig. 3). Until now, only limited data on $P$ of Corophium spp. have been published. Thus, Foster-Smith (1978) measured the $P$ of a $7 \mathrm{~mm} \mathrm{C}$. volutator to be $63 \pm 36 \mathrm{ml} \mathrm{h}^{-1}$ $\left(\sim 13^{\circ} \mathrm{C}\right)$, comparable to the $90 \mathrm{ml} \mathrm{h}^{-1}\left(15^{\circ} \mathrm{C}\right)$ estimated for amphipods of similar size in the present study (Fig. 3B).

The $F / R$ ratio which expresses the litres of water pumped per $\mathrm{ml}$ oxygen consumed can be used to characterise suspension feeders inhabiting inshore 
Table 3. Corophium volutator. Estimated grazing impact in 2001 at study site in inner Odense Fjord. $D$ : population density; $L$ : mean $( \pm \mathrm{SD}, \mathrm{n}=25)$ body length; $T$ : temperature; $F_{1}$ : mean individual filtration rate (=pumping rate); $F_{\text {pop }}$ : areaspecific population filtration rate; $Q$ : estimated grazing impact; $t_{1 / 2}=$ estimated potential half-life time of phytoplankton

\begin{tabular}{|lccccccc|}
\hline Month & $\begin{array}{c}D \\
\left(\text { ind. } \mathrm{m}^{-2}\right)\end{array}$ & $\begin{array}{c}L \\
(\mathrm{~mm})\end{array}$ & $\begin{array}{c}T \\
\left({ }^{\circ} \mathrm{C}\right)\end{array}$ & $\begin{array}{c}F_{\mathrm{i}} \\
\left(\mathrm{ml} \mathrm{h}^{-1} \mathrm{ind}^{-1}\right)\end{array}$ & $\begin{array}{c}F_{\text {pop }} \\
\left(\mathrm{m}^{3} \mathrm{~m}^{-2} \mathrm{~d}^{-1}\right)\end{array}$ & $\begin{array}{c}Q \\
(\mathrm{~h})\end{array}$ & $\begin{array}{c}t_{1 / 2} \\
(\mathrm{~h})\end{array}$ \\
\hline Jan & $3439 \pm 296$ & $7.5 \pm 0.6$ & 1.0 & 11.2 & 0.9 & 20.9 & 14.5 \\
Feb & $12469 \pm 3332$ & $4.5 \pm 0.4$ & 2.5 & 6.0 & 1.8 & 10.8 & 7.5 \\
Mar & $8668 \pm 3854$ & $4.9 \pm 1.0$ & 4.5 & 11.5 & 2.4 & 8.0 & 5.6 \\
Apr & $4052 \pm 1949$ & $6.0 \pm 0.6$ & 5.0 & 21.4 & 2.1 & 9.2 & 6.4 \\
May & $4523 \pm 743$ & $6.9 \pm 0.7$ & 10.1 & 61.6 & 6.7 & 2.9 & 2.0 \\
Jun & $10905 \pm 2120$ & $6.5 \pm 0.9$ & 15.0 & 74.0 & 19.4 & 1.0 & 0.7 \\
Jul & $17196 \pm 2856$ & $4.5 \pm 1.2$ & 20.0 & 44.9 & 18.5 & 1.0 & 0.7 \\
Aug & $18778 \pm 1716$ & $3.7 \pm 0.8$ & 19.0 & 25.4 & 11.4 & 1.7 & 1.2 \\
Sep & $18040 \pm 1918$ & $3.8 \pm 0.8$ & 14.0 & 19.6 & 8.5 & 2.3 & 1.6 \\
Oct & $13191 \pm 2243$ & $4.1 \pm 0.9$ & 12.0 & 19.6 & 6.2 & 3.1 & 2.1 \\
Nov & $10364 \pm 1843$ & $5.1 \pm 0.9$ & 8.0 & 21.8 & 5.4 & 3.5 & 2.4 \\
Dec & $5653 \pm 1884$ & $5.4 \pm 1.2$ & 3.5 & 12.0 & 1.6 & 1.8 & 8.2 \\
\hline
\end{tabular}

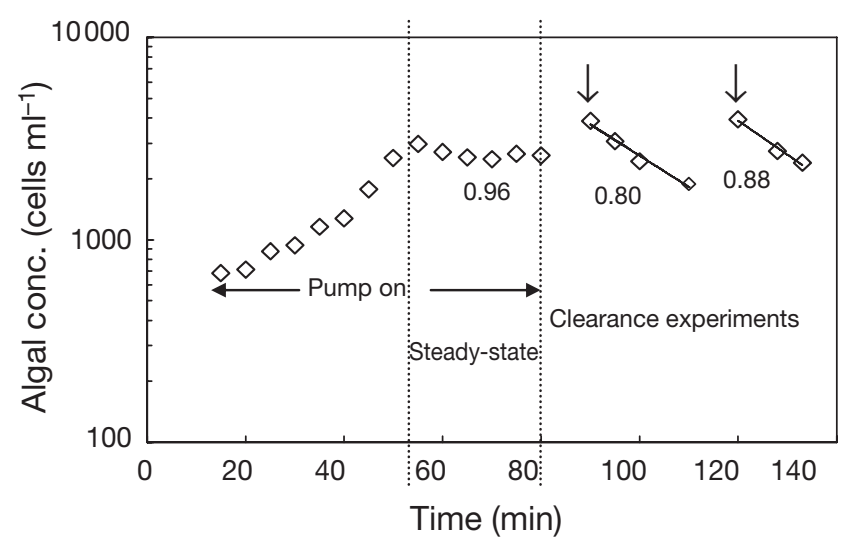

Fig. 7. Corophium volutator. Algal concentration as a function of time in Expt B, with burrowed individuals fed Tetraselmis sp. Algal cells were first continuously added to obtain a steady-state during which the population filtration capacity was estimated to be $F_{\mathrm{s}}=0.96 \mathrm{~m}^{3} \mathrm{~d}^{-1}$. The algae dosing pump was then switched off and 2 clearance measurements made; arrows indicate algae addition; regression lines and estimated population filtration rates $\left(F_{\mathrm{cl}}=0.80\right.$ and $\left.0.88 \mathrm{~m}^{3} \mathrm{~d}^{-1}\right)$ are given waters. For true suspension feeders (synonymous with filter feeders) this ratio generally exceeds $10 \mathrm{l}$ water $\mathrm{ml}^{-1}$ of oxygen consumed (Riisgård \& Larsen 2000). Relating the $P$ of Corophium volutator to $R$ measured in the present study results in an $F / R$ ratio of $108 \mathrm{l}$ water $\mathrm{ml}^{-1}$ oxygen consumed (Table 5). Table 5 also contains data from the literature. The ratios vary between 20 and $108 \mathrm{l}$ water $\mathrm{ml}^{-1}$ oxygen consumed, and indicate that C. volutator fulfils the conditions for classification as a true filter feeder, provided that the phytoplankton cells can be efficiently retained by the setae filter, i.e. are $\geq 7 \mu \mathrm{m}$. However, it should be noted that all $R$ in Table 5 were measured on free-swimming individuals. Harris \& Musko (1999) measured respiration in $C$. curvispinum both within and outside its tube, and found that the $R$ was about 2 times higher in free-swimming individuals.

In addition to suspended phytoplankton cells, the diet of Corophium volutator is versatile. In the surface deposit-feeding mode $C$. volutator can ingest benthic microalgae (mainly diatoms), detritus (grasses, macroalgae), bacteria (attached to mineral particles), and 'flocks' (amorphous precipitates of organic material), but the relative contributions of these various sources to its diet are unknown (Murdoch et al. 1986). In addition to swallowing particles, $C$. volutator is capable of episammic browsing, i.e. scraping and ingesting organic material from mineral particles of a larger size than the maximum size that can be swallowed (Nielsen \& Kofoed 1982). Because C. volutator lives in wind-, wave- and tidally impacted shallow waters, it may frequently be exposed to re-suspended bottom material. Therefore it seems likely that its filterfeeding ability may also be used for retaining

Table 4. Corophium volutator. Filtration Expts A to E performed in 2002 (Figs. 7 \& 8). T: temperature; L: body length; D: population density in aquarium; $\mathrm{n}=$ actively filter-feeding amphipods, $F_{\mathrm{s}}$ : filtration capacity measured by steady-state method using $8.6 \mu \mathrm{m}$ Tetraselmis sp. cells; $F_{\mathrm{cl}}$ : mean filtration capacity measured by clearance method; $F_{\text {pop }}\left(=D \times F_{s}\right)$ : area-specific population filtration rate; $F_{\mathrm{i}}$ : individual filtration rate (estimated from $F_{\mathrm{s}}$ ); $F_{\mathrm{i}, \text { est }}$ : individual filtration rate estimated from PTV experiments with individuals in glass tubes, corrected for size and temperature (Figs. 3B \& 6B)

\begin{tabular}{|c|c|c|c|c|c|c|c|c|c|c|}
\hline Expt & Date & $\begin{array}{c}T \\
\left({ }^{\circ} \mathrm{C}\right)\end{array}$ & $\begin{array}{c}L \\
(\mathrm{~mm})\end{array}$ & $\begin{array}{c}D \\
\left(\text { ind. } \mathrm{m}^{-2} \text { ) }\right.\end{array}$ & $n$ & $\begin{array}{c}F_{\mathrm{s}} \\
\left(\mathrm{m}^{3} \mathrm{~d}^{-1}\right)\end{array}$ & $\begin{array}{c}F_{\mathrm{cl}} \\
\left(\mathrm{m}^{3} \mathrm{~d}^{-1}\right)\end{array}$ & $\begin{array}{c}F_{\mathrm{pop}} \\
\left(\mathrm{m}^{3} \mathrm{~m}^{-2} \mathrm{~d}^{-1}\right)\end{array}$ & $\begin{array}{c}F_{\mathrm{i}} \\
\left(\mathrm{ml} \mathrm{h}^{-1}\right)\end{array}$ & $\begin{array}{c}F_{\mathrm{i}, \text { est. }} \\
\left(\mathrm{ml} \mathrm{h}^{-1}\right)\end{array}$ \\
\hline A & 4 May & 10 & $6.7 \pm 0.7$ & $\sim 2600$ & 360 & 0.5 & 0.4 & 3.2 & 54 & 55 \\
\hline B & 19 May & 12 & & & & 1.0 & 0.8 & 6.0 & & \\
\hline $\mathrm{C}$ & 20 May & 12 & & & & 0.7 & 0.7 & 4.6 & & \\
\hline $\mathrm{D}$ & 17 Jun & 17 & $4.1 \pm 1.3$ & $15389 \pm 1355$ & 2330 & 1.6 & & 10.4 & 28 & 32 \\
\hline E & 18 Jun & 17 & $4.1 \pm 1.3$ & $15389 \pm 1355$ & 2237 & 1.6 & & 10.3 & 29 & 32 \\
\hline
\end{tabular}


resuspended inorganic particles that it subsequently subjects to episammic browsing. Gut samples of C. volutator studied under the microscope by Murdoch et al. (1986) showed that the greater part of the gut volume consisted of mineral grains and, further, that bacteria made the maximum contribution to identifiable food items. In filter-feeding experiments with C. volutator, Fenchel et al. (1975) found that suspended bacteria were only captured when adsorbed to fine mineral particles.

In the present study, Corophium volutator was seasonally acclimated to 2 temperatures $\left(7\right.$ and $\left.15^{\circ} \mathrm{C}\right)$ to study the acute effect of temperature on filtration rate. While the beat frequency/pumping rate increased linearly with increasing temperature from 6 to $23^{\circ} \mathrm{C}$ for individuals acclimated at $15^{\circ} \mathrm{C}$, the beat frequency for individuals acclimated at $7^{\circ} \mathrm{C}$ increased linearly with temperature between only 6.5 and $15^{\circ} \mathrm{C}$, above which it decreased (Fig. 6A,B). Within the 'temperature-tolerance interval' at both temperatures, the slopes of the regression lines were equal. Comparable temperature effects have been observed in filter-feeding Nereis diversicolor acclimated to $6^{\circ} \mathrm{C}$ (Riisgård et al. 1992). Further, in mussels Mytilus edulis seasonally acclimated in the field to $18^{\circ} \mathrm{C}$, Kittner \& Riisgård (2005) recently observed that the temperature tolerance interval was extended downwards (from 8 to $4^{\circ} \mathrm{C}$ ) over a period of $5 \mathrm{~d}$ when the mussels had been acclimated to a temperature of $11^{\circ} \mathrm{C}$.

Our laboratory experiments showed that Corophium volutator filter feeds when sufficiently high concen- trations of suspended algal cells are present in the ambient water (Table 4). However, when the algal supply is cut off and the algal biomass subsequently decreases below a certain 'trigger level', the surface deposit-feeding activity increases, indicating a switch in feeding mode (Fig. 8). Likewise in the field, relative high surface deposit-feeding activities of both C. volutator and Nereis diversicolor were observed during periods of relatively low chl a concentrations (Fig. 9), in agreement with the results of previous studies in which the trigger level for $N$. diversicolor was found to be

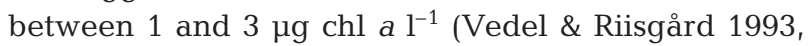
Vedel et al. 1994, Vedel 1998).

The $F_{\text {pop }}$ of Corophium volutator in Odense Fjord varied between 0.9 in January and $19.4 \mathrm{~m}^{3} \mathrm{~m}^{-2} \mathrm{~d}^{-1}$ in June (Table 3). By comparison, Vedel (1998) found an $F_{\text {pop }}$ of 1.7 to $6.9 \mathrm{~m}^{3} \mathrm{~m}^{-2} \mathrm{~d}^{-1}$ for Nereis diversicolor at the same site. The high area-specific population filtration capacities found for $C$. volutator suggest that the grazing impact of this facultative filter-feeding amphipod in many shallow water areas may be more significant than so far recognised.

Besides containing dense populations of Corophium volutator and Nereis diversicolor, Odense Fjord is also characterised by a large biomass of filter-feeding clams Mya arenaria and cockles Cerastoderma glaucum (Riisgård et al. 2004). In a recent field study, a strong interplay was found between filter feeders and hydrodynamics in the inner part of the shallow Odense Fjord (Riisgård et al. 2006). Modelling showed that a
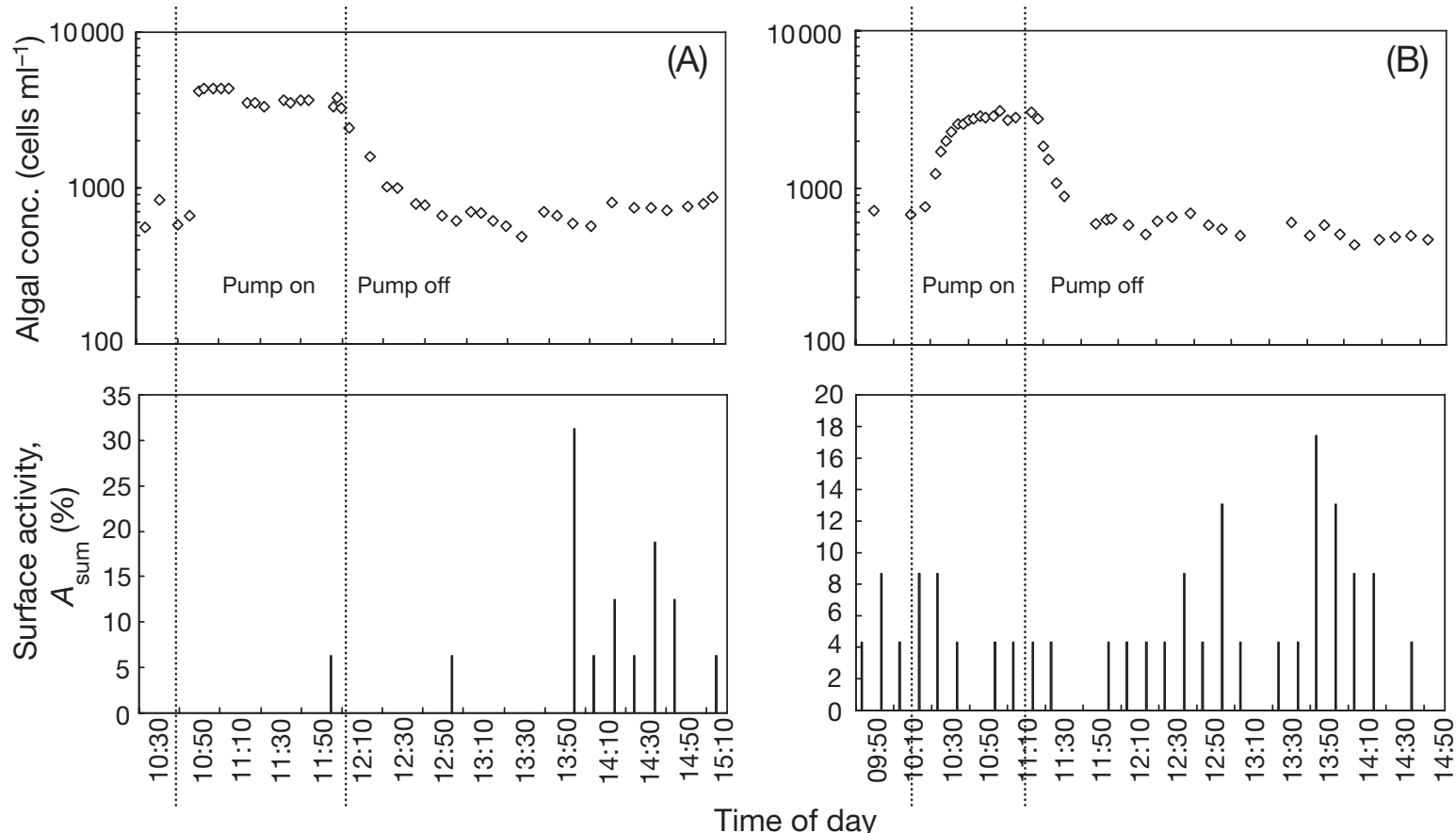

Fig. 8. Corophium volutator. Simultaneous recording of algal concentration (varied by switching dosing pump on or off) and surface deposit-feeding activity of amphipods in (A) Expt D and (B) Expt E 

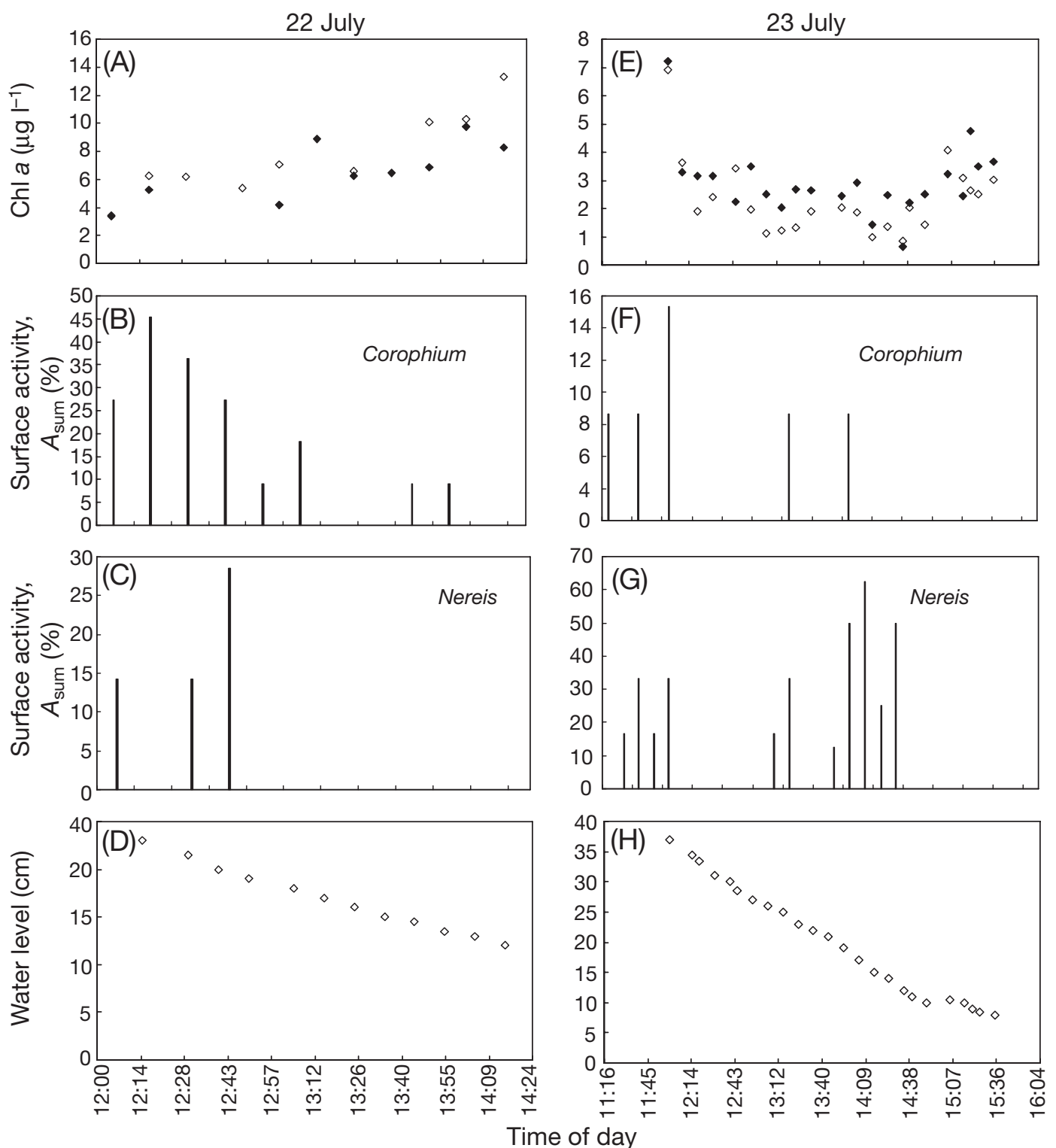

Fig. 9. Results of field observations in inner part of Ofense Fjord on $2 \mathrm{~d}$ in 2003. (A,E) Chlorophyll a concentrations measured $(\diamond)$ near fjord bottom and $(\diamond)$ near the water surface; (B,F) surface deposit-feeding activity of Corophium volutator; $(\mathrm{C}, \mathrm{G})$ surface deposit-feeding activity of Nereis diversicolor; $(\mathrm{D}, \mathrm{H})$ tidal change in water depth during observation period

fully mixed flow resulted in a potential half-life for phytoplankton of only $1.3 \mathrm{~h}$, whereas for incompletely mixed water the half-life was 2.7 times longer. A certain grazing impact was evident from vertical chl a profiles, often with strongly reduced near-bottom concentrations, but the impact was not sufficient to identify even the main biophysical processes that prevent suspension feeders from completely controlling the phytoplankton biomass in the inner Odense Fjord.
Table 5. Corophium volutator. Respiration measured in individuals without a tube. $T$ : temperature; $R$ : respiration estimated from different studies for a $6.5 \mathrm{~mm}$ standard individual; $F$ : filtration rate estimated from own results

(Figs. 3B \& 6B); F/R: liters of water pumped $\mathrm{ml}^{-1}$ of oxygen consumed

\begin{tabular}{|ccccc|}
\hline $\begin{array}{l}T \\
\left({ }^{\circ} \mathrm{C}\right)\end{array}$ & $\begin{array}{c}R \\
\left(\mu \mathrm{O}_{2} \mathrm{~h}^{-1}\right)\end{array}$ & $\begin{array}{c}F \\
\left(\mathrm{l} \mathrm{h}^{-1}\right)\end{array}$ & $\begin{array}{c}F / R \\
\left(\mathrm{l} \text { water } \mathrm{ml}^{-1} \mathrm{O}_{2}\right)\end{array}$ & Source \\
\hline 10 & 1.2 & 0.050 & 42 & Cammen et al. (1990) \\
10 & 1.1 & 0.050 & 45 & McLusky (1969) \\
12 & 0.6 & 0.060 & 100 & Harris \& Morgan (1984) \\
12 & 3.0 & 0.060 & 20 & Harris \& Morgan (1984) \\
15 & 0.7 & 0.074 & 108 & Hawkins (1985) \\
15 & $0.7 \pm 0.08$ & 0.074 & 108 & This study \\
\hline
\end{tabular}


Acknowledgements. We would like to thank the reviewers for their useful comments and linguistic improvements. H.U.R. was funded by a grant from the Danish Natural Science Research Council (grant no. 51-00-0314).

\section{LITERATURE CITED}

Cammen LM, Corwin S, Christensen JP (1990) Electron transport system (ETS) activity as a measure of benthic macrofaunal metabolism. Mar Ecol Prog Ser 65:171-182

Fenchel T, Kofoed LH, Lappalainen A (1975) Particle sizeselection of two deposit feeders: the amphipod Corophium volutator and prosobranch Hydrobia ulvae. Mar Biol 30: $119-128$

Flach EC (1992) The influence of four macrozoobenthic species on the abundance of the amphipod Corophium volutator on tidal flats of the Wadden Sea. Neth J Sea Res 15:196-216

Flach EC (1993) The distribution of the amphipod Corophium arinarium in the Dutch Wadden Sea: relationships with sediment composition and the presence of cockles and lugworms. Neth J Sea Res 31:281-290

Foster-Smith RL (1978) An analysis of water flow in tubeliving animals. J Exp Mar Biol Ecol 34:73-95

Foster-Smith RL, Shillaker RO (1977) Tube irrigation by Lembos websteri Bate and Corophium bonnelli Milne Edwards (Crustacea: Amphipoda). J Exp Mar Biol Ecol 26:289-296

Gerdol V, Hughes RG (1994a) Feeding behaviour and diet of Corophium volutator in an estuary in southeastern England. Mar Ecol Prog Ser 114:103-108

Gerdol V, Hughes RG (1994b) Effect of Corophium volutator on the abundance of benthic diatoms, bacteria and sediment stability in two estuaries in southeastern England. Mar Ecol Prog Ser 114:109-115

Hagerthey SE, Defew EC, Paterson DM (2002) Influence of Corophium volutator and Hydrobia ulvae on intertidal benthic diatom assemblages under different nutrient and temperature regimes. Mar Ecol Prog Ser 245:47-59

Harris GJ, Morgan E (1984) Rhythms of locomotion and oxygen consumption in the estuarine amphipod Corophium volutator (Crustacea: Amphipoda). Chronobiol Int 1:21-25

Harris RR, Musko IB (1999) Oxygen consumption, hypoxia, and tube dwelling in the invasive amphipod Corophium curvispinum. J Crustac Biol 19:224-234

Hart TJ (1930) Preliminary notes on the bionomics of the amphipod Corophium volutator Pallas. J Mar Biol Assoc UK 16:761-789

Hawkins CM (1985) Population carbon budgets and the importance of the amphipod Corophium volutator in the carbon transfer on a Cumberland basin mudflat, upper bay of Fundy, Canada. Neth J Sea Res 19:165-176

Kittner C, Riisgård HU (2005) Effect of temperature on filtration rate in the mussel Mytilus edulis: no evidence for temperature compensation. Mar Ecol Prog Ser 305:147-152

Lincoln RJ (1979) British marine Amphipoda: Gammaridea. British Museum (Natural History), London

McLusky DS (1969) The oxygen consumption of Corophium volutator in relation to salinity. Comp Biochem Physiol 29: $743-753$

Editorial responsibility: Otto Kinne (Editor-in-Chief), Oldendorf/Luhe
Meadows PS, Reid A (1966) The behaviour of Corophium volutator (Crustacea: Amphipoda). J Zool 150:387-399

Miller DC (1984) Mechanical post-capture particle selection by suspension- and deposit-feeding Corophium. J Exp Mar Biol Ecol 82:59-76

Möller P, Rosenberg R (1982) Production and abundance of the amphipod Corophium volutator on the west coast of Sweden. Neth J Sea Res 16:127-140

Murdoch MH, Barlocher F, Laltoo ML (1986) Population dynamics and nutrition of Corophium volutator (Pallas) in the Cumberland Bassin. J Exp Mar Biol Ecol 103: 235-249

Nielsen MV, Kofoed LH (1982) Selective feeding and epipsammic browsing by the deposit feeding amphipod Corophium volutator. Mar Ecol Prog Ser 10:81-88

Omori K, Tanaka M, Kikuchi T (1982) Seasonal changes of short-term reproductive cycle in Corophium volutator (Crustacea: Amphipoda) - semi-lunar or lunar cycle? Publ Amakusa Mar Biol Lab 6:105-117

Riisgård HU, Kamermans P (2001) Switching between deposit- and suspension feeding in coastal zoobenthos. In: Reise K (ed) Ecological studies. Sandy and muddy shores: ecological comparisons. Springer-Verlag, Berlin, p 73-101

Riisgård HU, Larsen PS (2000) Comparative ecophysiology of active zoobenthic filter feeding, essence of current knowledge. J Sea Res 44:169-193

Riisgård HU, Larsen PS (2005) Water pumping and analysis of flow in burrowing zoobenthos - an overview. Aquat Ecol 39:237-258

Riisgård HU, Randløv A (1981) Energy budgets, growth and filtration rates in Mytilus edulis at different algal concentrations. Mar Biol 61:227-234

Riisgård HU, Vedel A, Boye H, Larsen PS (1992) Filter-net structure and pumping activity in the polychaete Nereis diversicolor: effects of temperature and pump-modelling. Mar Ecol Prog Ser 83:79-89

Riisgård HU, Seerup DF, Hjort MH, Glob E, Larsen PS (2004) Grazing impact of filter-feeding zoobenthos in a Danish fjord. J Exp Mar Biol Ecol 307:261-271

Riisgård HU, Lassen J, Kortegaard M, Møller LF, Friedrichs M, Jensen MH, Larsen PS (2006) Filter-feeding zoobenthos and importance of hydrodynamics in the shallow Odense Fjord (Denmark) - earlier and recent studies, perspectives and modelling. Estuar Coast Shelf Sci (in press)

Taylor PM (1985) The pattern of gill perfusion in two species of Corophium and its relation to environmental salinity. J Zool 205:29-38

Vedel A (1998) Phytoplankton depletion in the benthic boundary layer caused by suspension-feeding Nereis diversicolor (Polychaeta): grazing impact and effect of temperature. Mar Ecol Prog Ser 163:125-132

Vedel A, Riisgård HU (1993) Filter-feeding in the polychaete Nereis diversicolor: growth and bioenergetics. Mar Ecol Prog Ser 100:145-152

Vedel A, Andersen BB, Riisgård HU (1994) Field investigations of pumping activity of the facultatively filter feeding polychaete Nereis diversicolor using an improved infrared phototransducer system. Mar Ecol Prog Ser 103:91-101

Submitted: December 23, 2005; Accepted: March 7, 2006 Proofs received from author(s): August 31, 2006 